\title{
Methanogens in the environment: an insight of methane yield and impact on global climate change
}

\author{
Ashish Kumar Pandey ${ }^{1^{*}}$, Neelava Das ${ }^{2}$, Muthu Kumar A. ${ }^{1}$, Srinivasa Rao ${ }^{3}$ \\ ${ }^{1}$ Forest \& Wood Protection Division, Institute of Wood Science \& Technology, Bangalore, India \\ ${ }^{2}$ Laboratory for Molecular Plant Physiology and Biotechnology, Department of Biology, University \\ of Antwerp, Groenenborgerlaan, B2020, Belgium \\ ${ }^{3}$ Forest Biometry Division, Institute of Wood Science and Technology, Bangalore, India \\ *E-mail address: apandeyiwst@gmail.com
}

Keywords: Methanogens; Global Warming; Archaea; Methane; Diversity

\begin{abstract}
Methane is a most important greenhouse gas for planetary heating and it's produced by methanogenic microorganisms as a metabolic byproduct and creates climate change. Methanogens are ancient organisms on earth found in anaerobic environments and methane is a key greenhouse gas concerned with methanogens. Therefore here is intense interest to writing this paper. A number of experiments have already conducted to study the methanogens in various environments such as rumen and intestinal system of animals, fresh water and marine sediments, swamps and marshes, hot springs, sludge digesters, and within anaerobic protozoa which utilize carbon dioxide in the presence of hydrogen and produce methane. The diversity of methanogens, belong to the domain Archaea and get involved in biological production of methane that catalyzes the degradation of organic compound as a part of global carbon cycle called methanogenesis. Majorly in this article we summaries the diversity of methanogens and their impact on global warming.
\end{abstract}

\section{INTRODUCTION}

Today's world is confronting serious issues viz rises up the greenhouse gas in the atmosphere. Methane is a most important greenhouse gas and their warming potential approximately 25 fold larger than $\mathrm{CO}_{2}$ (IPCC, 2007). Each year it does produce about $600 \mathrm{Tg}$ (Ehhalt et al, 2001) and discharge to the climate (EPA 2010) including agriculture, industry and waste management (Dlugokencky et al, 2011). Straight off a day's output of methane is an origin of alarm because of its contribution to planetary heating. Although this alarm can be well recognized in the fundamental basis for majority of atmospheric methane emission is often unfulfilled. About $37 \%$ methane used to emit from natural sources. Methane yield in the earth's atmosphere other than industry only can take place by methanogenic microorganisms, group of archaea that involve environmental corners with constrained oxygen concentration. For example, wetlands, rice fields, swamps, bogs, freshwater and marine environment, farming soils and the rumen of animals (Ollivier. 2000; Eckburg et al, 2005; Kusar and Avgustin. 2010). All the sources of methane emission concern with their methanogenic microbial symbionts.

Methanogens are strictly anaerobic microorganisms belong to the domain of archaea, a group phylogenetically distinct from each eukaryotes and bacteria. Biologically it converts $\mathrm{CO}_{2}$ to methane by methanogenesis using three different pathways: $\mathrm{CO}_{2}$ reducing, methylotrophic and acetoclastic (Ferry, 1994) and several enzymatic activities. Methanogenesis and the decline of organic material results a considerable contributor of planetary heating. It may not be a net contributor and merely its essence switch $\mathrm{CO}_{2}$ into $\mathrm{CH}_{4}$ which is a key powerful greenhouse gas. And our figured out information can expand the function of methanogens into new areas such as climate change. The current review article is serious about the production of methane employment by methanogens and their impact on climate modification. 


\section{METHANOGENS AND THEIR CLASSIFICATION}

Methanogens belong to area of life archaea, are the exceptional group of microorganisms, can produce their energy via methanogenesis. The unceasing improvement of molecular methods for this study of environmental microorganisms has facilitated the characterization of methanogens community. Methanogens range has already been studied and species were isolated from a extensive scale of environments: gut of terrestrial arthropods (Hackstein and Stumm, 1994), termite guts (Ohkuma et al., 1999), hydrothermal vents (Takai and Horikoshi, 1999), hydrocarboncontaminated soils (Watanabe et al., 2002), ocean (Reeburgh, 2007) sediment soils (Bridgham et al., 2013), freshwater (Borrel et al., 2011) and humans (Saengkerdsub and Ricke, 2014). Among submerged soils, rice field soils have been widely examined (Ramakrishnan et al., 2001). Natural wetlands were rarely investigated (Horn et al., 2003), and to the present of our knowledge, only one publication has described the methanogens in end-Permian extinction (Daniel et al., 2014).

Methanogens share a set of physiological characteristics, they are phylogenetically widely varied. Recently, methanogens are classifies into 6 orders (Methanobacteriales, Methanococcales, Methanomicrobiales, Methanosarcinales, Methanopyrales, Methanocellales) all belonging to the phylum Euryarchaeota. A new order of methanogens was recently proposed on the basis of sequences retrieved from human gut (Mihajlovski et al., 2010). Two names were subsequently proposed, Methanoplasmatales (Paul et al., 2012) and later Methanomassiliicoccales (Iino et al., 2013), were validated by the International Committee on Systematic of Prokaryotes (ICSP). This taxonomy is supported via 16S rRNA gene sequences as well as a number of additional standards, e.g., motility, electron microscopy images, colony morphology, growth rate and condition, substrates for methanogenesis, nutritional requirements, morphologies, Gram staining, lipid analysis, nucleic acid hybridization, $\mathrm{G}+\mathrm{C}$ content of the DNA and structures of cell envelopes (Boone and Whitman, 1988). Methanogens are abundant in a vast variety of anaerobic environments where they catalyze the terminal step within the anaerobic food chain by converting methanogenic substrates into methane.

\section{METHANOGENESIS}

Methanogenesis represents the only active metabolism of methanogens. For this metabolism, methanogens may solely use a restricted range of substrates basic from the anaerobic basement of the organic matter by hydrolytic and fermentative bacterium (Garcia et al, 2000). According to that Methanogens accept a terminal position in the microbial trophic chains. Consistent with the metabolic allocation acclimated today; one can ascertain the hydrogenotrophic, methylotrophic and acetotrophic group of methanogenesis (Garcia et al, 2000). Most of the methanogens are hydrogenotrophs that use $\mathrm{H} 2$ to scale back $\mathrm{CO} 2$ into methane (Liu and Whitman. 2008). The methylotrophic methanogens use alkyl radical compounds like alcohol, methylamines and methylsulfides and convert the alkyl radical of these compounds into $\mathrm{CH} 4$ via substrate-specific methyltransferases (Ferry. 1999). Abbreviation equivalents for this methanogenesis are acquired through an extra oxidation of a alkyl radical into $\mathrm{CO} 2$ through the methyl-oxidation pathway agnate to the aboriginal, accomplish the hydrogenotrophic pathway operating in reverse direction. An alternative of this pathway consists of the absolute use of $\mathrm{H} 2$ present in the environment associates in electron donor, rather than reducing equivalents made by the methyl-oxidation pathway. Apparently, the methanogens restricted to this alternative pathway begin to associate with the gut environments. Finally, few archaea are attached to the Methanosarcinales and clever to use acetate as substrate for methanogenesis (Whiticar et al, 1986).

\section{METHANOGENS DIVERSITY AND METHANE PRODUCTION}

\subsection{IN RUMEN ENVIRONMENTS}

In recent years, interests of methanogenic bacteria from ruminating animals have extended (Hook et al. 2010). A number of experimental approaches had been carried out to reach the knowledge of the methanogens population in the rumen of animals such as cattle and sheep. The 
rumen methanogens also different to rely on their diet and geographical location. Among livestock, production of methane is higher in ruminants that methanogens ready to produce methane freely through the usual method of feed digestion.

Methane is a potential greenhouse gas and its formation in the rumens further leads to global warming (Yousuf et al. 2012). Inside the agriculture sector, principal source of methane is from ruminant animals (Ellis et al, 2007). A ruminant, such as cattle, sheep and goats produces 86 million metric tons (Tg) of methane per year (McMichael et al, 2007). Approximately 18.9 $\mathrm{Tg}$ are from dairy cattle, 55.9 Tg from beef cattle and 9.5 Tg are from sheep and goats (McMichael et al, 2007). Methane is produced in the rumen as a product of normal fermentation of feed stuffs and the loss of methane to the atmosphere varies based on the ruminant species. Methanobrevibacter ruminantium and Methanomicrobium mobile were found to the major methanogens in the rumen (Yanagita et al, 2000).

Although now no conclusive answer has been raised up regarding the regulation factors involve methane production in ruminating animals (Wright and Klieve 2011). Moreover, the evaluation of methanogens in rumen has revealed the variation of individuals as an impact of diet and climatic conditions (King et al. 2011; Kumar S et al. 2009). Among the published studies, dominant methanogens in the rumen regarding the genus Methanobrevibacter, no difference was detected in whole population of methanogens in the rumen. But Methanobrevibacter ruminantium was only species whose genome has been sequenced. However, DNA based tools (Kittelmann et al., 2013) are still being used to decipher differences in microbial community structures in animals with different productivity traits, such as differences in feed conversion efficiency (Carberry et al., 2014).

\subsection{MARINE ENVIRONMENTS}

Oceans had been observed to be a minor supply of methane to the environment, accounting for $2-10 \%$ of the worldwide emissions (Bange et al., 1994). An enhanced emission estimate from marine seeps suggests these sources may contribute $\sim 20 \mathrm{Tg}$ methane $\mathrm{yr}^{-1}$, i.e., $4 \%$ of the worldwide emissions, to the atmospheric methane (Etiope et al., 2008). A foremost fraction of the oceanic supply (75\%) is notion to originate from estuaries, 15 shelf and coastal areas (Bange, 2006; Bange et al., 1994). For example, the European coastal areas were observed to emit $0.46-1 \mathrm{Tg}^{-1}{ }^{-1}$, and accordingly make a great contribution create the total global methane oceanic emissions (Bange, 2006).

In marine and freshwater environments, the conversion of organic matter to methane by microbial consortia (Barber and Ferry. 2001). Within the marine environment, methanogens are wide range of morphological shapes with physiological tolerances which includes psychrophiles from an Antarctic lake that grow at $1.7^{\circ} \mathrm{c}$ to severe thermophiles from deep sub marine thermal vents $\mathrm{t}$ which grow at $113^{\circ} \mathrm{c}$ and acidophiles which grow at $\mathrm{P}^{\mathrm{H}} 5.0$ to alkaliphiles from sediments that grow at $\mathrm{P}^{\mathrm{H}}$ 9.0. Approximately one third of the total described species of methanogens are of marine origin and occurring in four of the five orders within the kingdom Euryarchaeota of the archaeal domain (Ferry and Kastead. 2007). Only two species isolated from marine environments are able to make use of acetate; Methanosarcina acetovorans and Methanosarcina siciliae (Elberson and Sowers. 1997). Finally the order Methanopyrales contains a single rod shaped species, Methanopyrus kandlerii that grow at or above the boiling point of water using only $\mathrm{H}_{2}$ and $\mathrm{CO}_{2}$ as carbon and energy sources.

\subsection{WETLAND ENVIRONMENTS}

Wetlands also contribute to the atmospheric methane concentration (Baumgartner et al, 2012) and the largest supplier of methane including bogs, peatlands, swamps and marshes. It contributes one quarter of global methane emissions (Kirschke et al, 2013). The methane emission from wetlands increased with the aid of 7\% on 2003 (Bloom et al., 2010). Although wetlands comprise only about 5-8\% of the terrestrial land surface (Mitsch and Gosselink 2007). It is estimated that wetlands emit 20-25\% of current global methane emissions, or about $115-227 \mathrm{Tg} \mathrm{CH}_{4} \mathrm{yr}^{-1}$ 
(Whalen 2005; Bergamaschi et al. 2007; Bloom et al. 2010). Rice paddies account for about 60-80 $\mathrm{Tg} \mathrm{CH}_{4} \mathrm{yr}^{-1}$ of methane emissions. The methanogenic microorganisms dwelling within wetland environments are poorly characterized till now.

Up to date, many studies have focused on the $\mathrm{CH}_{4}$ emission from wetland ecosystems, in an attempt to quantify the $\mathrm{CH}_{4}$ source strengths from wetlands (Christensen et al., 2003). Meanwhile, many process-based models have been developed to predict $\mathrm{CH}_{4}$ emissions from natural wetlands (Petrescu et al., 2010). Nonetheless, there's great uncertainty in the magnitude and distribution of $\mathrm{CH}_{4}$ sources from regional to global scales due to the fact of the huge spatial and temporal variations in emissions across individual wetland types (Chen et al., 2008). Several factors that affect $\mathrm{CH}_{4}$ emissions had been recognized, such as temperature (Westermann, 1993), plant type (Bartlett et al., 1992), primary production (Whiting and Chanton, 1993), the water table (Ding et al., 2010), and the thaw depth at permafrost sites (Walter and Heimann, 2000). Covey et al, (2012) concluded that methane emission from dead trees under anaerobic condition. Cavicchioli R. (2006) concluded that methanogens are abundant in cold environments and Methanosaetaceae, Methanosarcinaceae, Methanobacteriaceae and Methanomicrobiales are often identified as the dominant methane producers in Arctic wetlands (Hoj et al. 2005). Ding et al. (2004) suggested that the high elevation (height above sea level: $>3400 \mathrm{~m}$ ) of the Ruoergai peatlands in the Qinghai Tibetan Plateau results in low temperatures in summer, which flip lowers the deliver of methanogenic substrates and $\mathrm{CH}_{4}$ production. Chasar et al. (2000) concluded that the $\mathrm{CH}_{4}$ production in wetlands is suffering from the acetate provide through acetate fermentation and the $\mathrm{CO}_{2}$ reduction potential. On the basis of a study carried out in an ombrotrophic bog in Michigan. Avery et al. (2003) cited that the exponential increase within the rate of $\mathrm{CH}_{4}$ production with temperature is due to an increase in the number of available substrates and is not associated with changes in the composition and populations of methanogens.

Stoeva et al, (2014) studied that methane emission and methanogens diversity are highest at the surface of lake sediments but deeper in wetland sediments. Methanosarcina spp. and Methanosaeta spp. are dominant in wetland environments. To date, little is known concerning the dimension of the methanogenic archaeal population and the $\mathrm{CH}_{4}$ production potential in freshwater natural wetlands.

\section{ENZYMES INVOLVED IN METHANE PRODUCTION}

The intricacy and individuality of methanogenesis as a type of anaerobic respiratory resides in the requirement of six remarkable coenzymes ferredoxin, methanofuran, methanopterin, coenzyme F420, coenzyme M and coenzyme B: a pathway and a number of particular membrane bound enzyme complexes coupled to the production of a proton gradient driving ATP synthesis (Ferry, 2010). The three primary methanogenic substrates are $\mathrm{CO}_{2}$, acetate and methyl group containing compounds such as methanol, methylated amines and methylated sulfides. For this reason, three distinct hydrogenotrophic, acetoclastic and methylotrophic respectively pathways for $\mathrm{CH}_{4}$ production exist (Ferry, 1999; Deppenmeier, 2002). Even though the intermediates and enzymatic reactions of the three pathways are specific, they share customary facets within the final steps of $\mathrm{CH}_{4}$ production. The hydrogenotrophic and acetoclastic pathways each influence within the yield of a carrier bound methyl intermediate. The carrier protein is methanopterin in the hydrogenotrophic pathway and sarcinapterin, a spinoff of methanopterin, within the acetoclastic pathway. The switch of the methyl group to coenzyme $\mathrm{M}$ by means of a specific, membrane bound methyltransferase, and the subsequent reduction of methyl coenzyme $\mathrm{M}$ to $\mathrm{CH}_{4}$ through the important thing enzyme methyl coenzyme $\mathrm{M}$ reductase (Thauer, 1998), is common in all three pathways. The three methanogenic pathways are described in additional small print in assisting knowledge. methyl coenzyme $M$ reductase consists of a dimer of three subunits, $\alpha$ (McrA), $\beta$ (McrB) and $\gamma(\mathrm{McrG})$, and contains a unique porphinoid nickel containing active site called coenzyme F430 (Gunsalus and Wolfe, 1980). The enzymes apparent molecular mass is about $300 \mathrm{kDa}$. Two specified isoenzymes of methyl coenzyme M reductase had been identified (Steigerwald et al., 1993). The second enzyme, designated methyltransferase for methyl reductase two, has another substrate affinity 
(Bonacker et al., 1993). Methyl coenzyme M reductase activity is encoded by way of the mcrBDCGA operon, while the mrtBDGA operon codes for the MRT (Thauer, 1998). The identical of the gene mcrC is missing within the mrt operon (Pihl et al., 1994). The products of the genes mcrC (McrC), mcrD (McrD) and mrtD (MrtD) are beneath $20 \mathrm{kDa}$. Their operate remain to be unknown (Reeve et al., 1997). Primary sensors and signal transduction cascades have not been elucidated. Nonetheless, proof was discovered for regulation through trace elements and their availability (Hedderich and Whitman, 2006). This is on the grounds that many enzymes of methanogenesis contain trace metals (molybdenum, tungsten, selenium, nickel) in their active site. Availability of the substrate $\mathrm{H}_{2}$ was determined to control the formation of some key enzymes of methanogenesis together with MRC. In Methanothermobacter species, the expression of the two isoenzymes of methyl coenzyme $\mathrm{M}$ reductase is differentially regulated with the aid of $\mathrm{H}_{2}$ availability, with isoenzyme I (methyl coenzyme $\mathrm{M}$ reductase) predominantly expressed in $\mathrm{H}_{2}$ limiting environment (Morgan et al., 1997). The regulation of gene expression in methanogens remains to be not fully understood and needs additional study.

\section{ROLE OF METHANE AS A GREENHOUSE GAS}

The steadiness between sources and sinks of $\mathrm{CH}_{4}$ changed in the past century, leading to the expand in atmospheric $\mathrm{CH}_{4}$ of about $1.1 \mu \mathrm{l}^{-1}$ (ppmv), or $160 \%$, on account to that the $1850 \mathrm{~s}$. Atmospheric $\mathrm{CH}_{4}$ concentrations are currently double the maximum concentration recorded in a 420,000 year ice core (Petit et al. 1999). Global anthropogenic sources of $\mathrm{CH}_{4}$ quantity to $375 \mathrm{Tg}$ $\mathrm{yr}^{-1}$ (Schlesinger et al. 1997). These comprise fossil fuel related industries (100 $\left.\mathrm{Tg}_{\mathrm{gr}}{ }^{-1}\right)$, waste management $\left(90 \mathrm{Tg} \mathrm{yr}^{-1}\right)$, enteric fermentation $\left(85 \mathrm{Tg} \mathrm{yr}^{-1}\right)$, rice agriculture $\left(60 \mathrm{Tg}^{-1}\right)$ and biomass burning $\left(40 \mathrm{Tg} \mathrm{yr}^{-1}\right)$. On the natural sources, wetlands are $70 \%\left(160 \mathrm{Tg} \mathrm{yr}^{-1}\right)$ of the total. Upland ecosystems are almost always vied to be net sinks for $\mathrm{CH}_{4}$, consumption through soils amounting to $30 \mathrm{Tg} \mathrm{yr}^{-1}$ or about $6 \%$ of the global sink (Schlesinger et al. 1997). Global $\mathrm{CH}_{4}$ budgets often estimate a missing source of about $10 \mathrm{Tg}^{-1}{ }^{-1}$, which probably defined by using surprising emissions from upland ecosystems or adjustments to any of the known $\mathrm{CH}_{4}$ sources and sinks. Keppler et al. (2006) estimated anaerobic plant source of $149 \mathrm{Tg} \mathrm{yr}^{-1}$, which rivals all natural $\mathrm{CH}_{4}$ sources and would drive a reevaluation of the global $\mathrm{CH}_{4}$ budget. Revised estimates of the proposed aerobic plant source are low adequate to be accommodated within the uncertainty in the global $\mathrm{CH}_{4}$ budget (Butenhoff and Khalil 2007). Interest in $\mathrm{CH}_{4}$ emissions as a reason of radiative local climate forcing arises for the reason that, on a molar basis, $\mathrm{CH}_{4}$ is 3-22 times instances superior as a greenhouse gas than $\mathrm{CO}_{2}$, depending on the timeframe viewed. Methane concentrations are more responsive than $\mathrm{CO}_{2}$ to changes in sources or sinks on account that of a way shorter atmospheric dwelling time (12 years versus $>100$ years), inspiring suggestions that efforts to gradual the percent of global warming can focus firstly on abating $\mathrm{CH}_{4}$ emissions (Hansen et al. 2000). Thus, the Keppler et al. (2006) document of aerobic $\mathrm{CH}_{4}$ emissions generated a lot public interest (Lowe 2006).

\section{IMPACT OF ENVIRONMENTS BY METHANOGENS}

Methanogens play a pivotal role in methane emission in anaerobic condition through methanogenesis. Methane production in soils, sediments and sea bottoms by no means reach the surrounding and finally it's consumed by bacteria. But, a biogenic production of methane isn't consumed by the way of bacteria. In some environments correspond to shallow sediments, marshes; rice paddies etc do attain the atmosphere. Switch of methane from anaerobic environments to surrounding is used by plants. Methane production both in fermentation or landfills is quite often free to the atmosphere and reaches the stratosphere where they reacts with free radicals to form $\mathrm{CH}_{3}{ }^{+}$, which can then results in both production and destruction of ozone. Methane is a predominant greenhouse gas and has superior infrared absorbance. Methanogens play an important role in global carbon cycle by the way of recycling carbon from anaerobic decomposition of organic matter to the aerobic environments. 
Methanogens also have potential to degrade major pollutants (Lowe et al., 1993). A number of studies have performed using bacteria for the degradation of several organic compounds reminiscent of tetrachloroethylene and trichloroethylene. These compounds are utilized in dry cleaning and degreasing operation, plastic manufacture and many others.

\section{CURRENT STATUS AND FUTURE PERSPECTIVE}

However, new technologies are still confined by using DNA extraction, PCR, sequencing and probe biases, as well as a lack of bioinformatics support for next-generation sequencing and metaproteomics. Nevertheless, this field has seen a notable progress in most recent years as the bioinformatics tool develops; the following dispute will generate quantitative information for microbes concerned in the $\mathrm{CH}_{4}$ cycle and to parameterize these data for significant use in climate and ecosystem models.

Many methanogens and methanotrophs are uncultivable and for the reason little is legendary about their metabolic capabilities. This is a key requirement for positive inclusion of microbial information into the predictive forms. Approaches akin to DNA and RNA, stable isotope probing can assist for making a choice of physiological capabilities of individual species. There is knowledge obstacles with DNA and RNA, stable isotope probing techniques as reasonably excessive concentration of substrate have got to be used to accomplish sufficient labeling of DNA (Neufeld et al., 2007; 2008). Stable isotope probing pooled with PLFA (PLFA-SIP) can become aware of active microbes at environmentally relevant concentration. However, this approach lacks phylogenetic resolution to perfectly identify microorganisms at the species stage. Technological advances in SIP and complementary equipment are actually being made the place environmentally significant concentrations of substrate can be utilized for metagenomic and metaproteomic work (Murrell and Whiteley, 2011).

Moreover Classification of niches for populations of methanogens and methanotrophs is needed. Therefore in earlier there was a proof for niche adaptation in methanogens (Yavitt et al., 2012) and methanotrophs (Kumaresan et al., 2011; Nazaries et al., 2011). But after that, Reim and colleagues (2012) detected vertical niche differentiation in gamma proteobacterial methanotrophs inside the first three milli metres of water saturated soils. This is pretty significant and that signifies the need for perticular niche identification in view of neighborhood trade that can be determined in such a small scale.

\section{CONCLUSION}

If we can determine the niche separation for specific microbial groups with defined physiological capabilities and their regulation, this will incredibly help with the incorporation of microbial information into predictive models determination (Hoet al., 2013). And in further such information can also explore wide information regarding the methane production and deployment of specific unknown genes as a molecular avenue.

\section{Acknowledgment}

We thank to Dr. V Ramakantha, Director, Institute of Wood Science and Technology, Bangalore for providing the necessary facilities.

\section{References}

[1] Avery, G. B., Shannon, R. D., White, J. R., Martens, C. S., and Alperin, M. J. Biogeochemistry 62 (2003) 19-37.

[2] Bange, H. W., Bartell, U. H., Rapsomanikis, S., and Andreae, M. O. Global Biogeochem. Су. 8 (1994) 465-480.

[3] Bange, H. W. Estuar. Coast. Shelf S 70 (2006) 361-374. 
[4] Barber, R.D. and J.G. Ferry. Methanogenesis. eLS. (2001)

[5] Bartlett, K. B., Crill, P. M., Sass, R. L., Harriss, R. C., and Dise, N. B. J. Geophys. Res 97 (1992) 16645-16660.

[6] Baumgartner, M., Schilt, A., Eicher, O., Schmitt, J., Schwander, J., Spahni, R., Fischer, H., and Stocker, T. F. Biogeosciences 9 (2012) 3961-3977.

[7] Bergamaschi PC, Frankenberg C, Meirink JF, Krol M, Dentener F, Wagner T. Platt U, Kaplan JO, Ko"rner S, Heimann M, Goede A. J Geophys Res 112 (2007).

[8] Bloom AA, Palmer PI, Fraser A, Reay DS, Frankenberg C. Science 327 (2010) 322-325.

[9] Bonacker, L.G., Baudner, S., Morschel, E., Bocher, R., and Thauer, R.K. Eur J Biochem 217 (1993) 587-595

[10] Boone, D. R. \& Whitman, W. B. Int J Syst Bacteriol 38 (1988) 212-219.

[11] Borrel G, Jézéquel D, Biderre-Petit C, Morel-Desrosiers N, Morel JP, Peyret P, Fonty G, Lehours AC. Res Microbiol 162 (2011) 832-847.

[12] Bridgham, S.D, Cadillo-Quiroz H, Keller JK, Zhuang Q. Glob Chang Biol 2013; 19 (2013) 1325-1346.

[13] Butenhoff, C.L. andM.A.K. Khalil. Environ. Sci. Technol. 41 (2007) 4032-4037.

[14] Carberry CA, Waters SM, Kenny DA, Creevey CJ. 2014. Applied and Environmental Microbiology 80:2 (2014) 586-594.

[15] Cavicchioli R. Nature Reviews Microbiology 4 (2006) 331-343.

[16] Chasar, L. S., Chanton, J. P., Glaser, P. H., Siegel, D. I., and Rivers, J. S. Global Biogeochem. Cycl. 14 (2000) 1095-1108.

[17] Chen, H., Yao, S. P., Wu, N., Wang, Y. F., Luo, P., Tian, J. Q., Gao, Y. H., and Sun, G. J. Geophys. Res. 113 (2008) D12303, doi:10.1029/2006JD008072, 2008

[18] Christensen, T. R., Panikov, N., Mastepanov, M., Joabsson, A., Stewart, A., O“ quist, M., Sommerkorn, M., Reynaud, S., and Svensson, B. Biogeochemistry 64 (2003) 337-354.

[19] Covey, K. R., Wood, S. A., Warren, R. J., Lee, X. and Bradford, M. A. Geophys. Res. Lett. 39 (2012) L15705.

[20] Daniel H. Rothmana, Gregory P. Fournier, Katherine L. French, Eric J. Alm, Edward A. Boyle, Changqun Cao, and Roger E. Summons. PNAS. 111:15 (2014) 5462-5467.

[21] Deppenmeier, U. Prog Nucleic Acid Res Mol Biol 71 (2002) 223- 283.

[22] Ding, W. X., Cai, Z. C., and Wang, D. X. Atmos. Environ. 38 (2004) 751-759.

[23] Ding, W. X., Zhang, Y. H., and Cai, Z. C. Atmos. Environ. 44 (2010) 3894-3900.

[24] Dlugokencky EJ, Nisbet EG, Fischer R, Lowry D. Philos. T. Roy. Soc. A 369 (2011) 20582072.

[25] Eckburg, P.B., Bik, E.M., Bernstein, C.H.N., Purdom, E., Dethlefsen, L et al. (2005) Science 308 (2005)1635-1638.

[26] Ehhalt D, Prather M, Dentener F, Derwent R, Dlugokencky E, et al. Atmospheric Chemistry and Greenhouse Gases. In: Houghton JT, Ding Y, Griggs DJ, Noguer M, van der Linden PJ, Dai X, Maskell K, Johnson CA, editors. Climate Change 2001: The Scientific Basis. Contribution of Working Group I to the Third Assessment Report of the IPCC. Cambridge, United Kingdom and New York: Cambridge University Press. (2001) 239-287.

[27] Elberson, M.A. and Sowers, K.R. Int J Syst Bacteriol 47 (1997) 1258-1261. 
[28] Ellis JL, Kebreab E, Odongo NE, McBride BW, Okine EK, France J. Journal of Dairy Science. 90:7 (2007) 3456-3467.

[29] EPA. Methane and nitrous oxide emissions from natural sources Washington. EPA 430-R10-001. U.S. Environmental Protection Agency. (2010) 194p.

[30] Etiope, G., Lassey, K. R., Klusman, R. W., and Boschi, E. Geophys. Res. Lett. 35 (2008) L09307.

[31] Ferry JG. FEMS Microbiol Rev 23 (1999) 13-38.

[32] Ferry, J.G. \&K.A.Kastead. Methanogenesis. In Archaea: Molecular Cell Biology. R. Cavicchioli, Ed. (2007) 288-314. Washington, D.C.: ASM Press.

[33] Ferry, J.G. FEMS Microbiol Rev 23 (1999) 13-38

[34] Garcia JL, Patel BK, Ollivier B. Anaerobe 6 (2000) 205-226.

[35] Gunsalus, R.P., and Wolfe, R.S. J Biol Chem 255 (1980) 1891-1895.

[36] Hackstein, J.H.P. and Stumm, C.K. Proceedings of the National Academy of Sciences, USA 91 (1994) 5441-5445.

[37] Hansen, J., M. Sato, R. Ruedy, A. Lacis and V. Oinas. Proc. Natl. Acad. Sci. USA 97 (2000) 9875-9880.

[38] Hedderich, R., and Whitman, W. Physiology and bio- chemistry of the methane-producing Archaea. InThe Prokaryotes. Dworkin, M., Falkow, S., Rosenberg, E., Schleifer, K.H., and Stackebrandt, E. (eds). New York, USA: Springer, pp. (2006) 1050-1079.

[39] Hoj L, Olsen RA, Torsvik VL (2005) Fems Microbiology Ecology 53 (2005) 89-101.

[40] Hook SE, Wright ADG, McBride BW. Archaea (2010)1-11.

[41] Horn, M.A., Matthies, C., Kusel, K., Schramm, A. and Drake, H.L. Applied and Environmental Microbiology 69 (2003) 74-83.

[42] Iino T, Tamaki H, Tamazawa S, Ueno Y, Ohkuma M, Suzuki K, Igarashi Y, Haruta S. Microbes Environ 28 (2013) 244-250.

[43] IPCC (2007) Climate change 2007. the physical science basis. In Contribution of Working Group I to the Fourth Assessment Report of the Intergovernmental Panel on Climate Change (IPCC. Solomon, S., Qin, D., Manning, M., Chen, Z., Marquis, M., Averyt, K.B., et al (eds). Cambridge, UK and New York, NY, USA: Cambridge University Press

[44] J. G. Ferry. Biochemistry of Acetotrophic Methanogenesis. Handbook of Hydrocarbon and Lipid Microbiology. (2010) pp 357-367

[45] J.G.Ferry. Methanogenesis - Ecology, Physiology, Biochemistry \& Genetics, 1994

[46] King EE, Smith RP, St-Pierre B, Wright ADG. Appl. Environ. Microbiol. 77 (2011) 56825687.

[47] Kirschke, et al. Nature Geoscience. (2013) doi:10.1038/ngeo1955

[48] Kittelmann S, Seedorf H, Walters WA, Clemente JC, Knight R, Gordon JI, Janssen PH. PLoS ONE 8:2 (2013):e47879

[49] Kumar S, et al. World J. Microbiol. Biotechnol 25 (2009)1557-1566.

[50] Kumaresan, D., Hery, M., Bodrossy, L., Singer, A.C., StralisPavese,N.,Thompson,I.P.,andMurrell,J.C. Res Microbiol 162 (2011)1027-1032.

[51] Kusar D, Avgustin G (2010) FEMS Microbiol. Ecol. 74 (2010) 1-8.

[52] Liu Y, Whitman WB. Ann N Y Acad Sci 1125 (2008) 171-189 
[53] Lowe SE, Jain MK and Zeikus JG. Microbiological Reviews 57 (1993)451-509.

[54] Lowe, D.C. A green source of surprise. Nature 439 (2006)148-149.

[55] Magdalena K. Stoeva, Stéphane Aris-Brosou, John Chételat, Holger Hintelmann, Philip Pelletier, Alexandre J. Poulain. 2014. PLoS ONE 9:3 (2014) e89531

[56] McMichael AJ, Powles JW, Butler CD, Uauy R. The Lancet. 370:9594 (2007)1253-1263

[57] Mihajlovski A, Doré J, Levenez F, Alric M, Brugère JF. Environ Microbiol Rep 2 (2010) 272-280

[58] Mitsch WJ, Gosselink JG (2007) Wetlands, 4th edn. Wiley,Hoboken

[59] Morgan, R.M., Pihl, T.D., Nolling, J., and Reeve, J.N. J Bacteriol 179 (1997) 889-898.

[60] Murrell, J.C., and Whiteley, A.S. Stable Isotope Probing and Related Technologies. Washington, DC, USA: ASM Press (2011).

[61] Nazaries L., Tate K. R., Ross J. D., Singh J., et al. ISME J. 5 (2011) 1832-1836.

[62] Neufeld, J.D., Chen, Y., Dumont, M.G., and Murrell, J.C. Environ Microbiol 10 (2008) $1526-1535$.

[63] Neufeld, J.D., Dumont, M.G., Vohra, J., and Murrell, J.C. Microb Ecol 53 (2007) 435-442.

[64] Ohkuma, M., Noda, S. and Kudo, T. FEMS Microbiology Letters 171 (1999) 147-53.

[65] Ollivier B. Anaerobe 6 (2000) 205-226.

[66] Paul K, Nonoh JO, Mikulski L, Brune A. Appl Environ Microbiol 78 (2012) 8245

[67] Petit,J.R.,J.Jouzel,D.Raynaudetal. Nature 399 (1999) 429-436

[68] Petrescu, A. M. R., van Beek, L. P. H., van Huissteden J., Prigent, C., Sachs, T., Corradi, C. A. R., Parmentier, F. J.W., and Dolman A. J. Global Biogeochem. Cycl. 24 (2010) GB4009

[69] Pihl, T.D., Sharma, S. and Reeve, J.N. Journal of Bacteriology 176 (1994)6384-6391

[70] Ramakrishnan, B., Lueders, T., Dunfield, P.F., Conrad, R. and Friedrich, M.W. FEMS Microbiology Ecology 37 (2001)175-186

[71] Reeburgh WS. Chem Rev 107 (2007) 486-513.

[72] Reeve, J.N., Nolling, J., Morgan, R.M., and Smith, D.R. J Bacteriol 179 (1997) 5975-5986

[73] Reim, A., Lüke, C., Krause, S., Pratscher, J., and Frenzel, P. ISME J 6 (2012) 2128-2139.

[74] Saengkerdsub S, Ricke SC. Crit Rev Microbiol 40 (2014) 97-116

[75] Schlesinger, W.H. Biogeochemistry: an analysis of global change. Academic Press, San Diego, CA, (1997) 588 p.

[76] Steigerwald, V.J., Stroup, D., Hennigan, A.N., Palmer, J.R., Pihl, T.D., Daniels, C.J., and Reeve, J.N. Methyl coenzyme-M reductase II genes and their close linkage to the methyl viologen-reducing hydrogenase-polyferredoxin operon in the genomes of Methanobacterium thermoautotrophicum and Methanothermus fervidus. In Industrial Microorganisms: Basic and Applied Molecular Genetics. Baltz, R.H., Hegeman, G.D., and Skatrud, P.L. (eds). Washington, DC, USA: American Society for Micro- biology Press, pp. (1993) 109-115.

[77] Takai, K. and Horikoshi, K. Genetics 152 (1999) 1285-1297.

[78] Thauer, R.K. Microbiology 144 (1998) 2377- 2406.

[79] Walter, B. P. and Heimann, M. Global Biogeochem. Cycl. 14 (2000) 745-765. 
[80] Watanabe, K., Kodama, Y., Hamamura, N. and Kaku, N. Applied \& Environmental Microbiology 68 (2002) 3899-3907.

[81] Westermann, P. Chemosphere 26 (1993) 321-328.

[82] Whalen SC. Environ Eng Sci 22 (2005)73-94

[83] Whiticar MJ, Faber E, Schoell M. Geochim Cosmochim Acta 50 (1986) 693-709

[84] Whiting, G. J. and Chanton, J. P. Nature 364 (1993) 794-795

[85] Woese CR, Magrum LJ, Fox GE. J Mol Evol 11 (1978) 245 - 252.

[86] Wright ADG, Klieve AV. Anim. Feed Sci. Technol. (2011)166-167:248-253

[87] Yanagita K, Kamagata Y, Kawaharasaki M, Suzuki T, Nakamura Y, Minato H. Bioscience, Biotechnology and Biochemistry 64:8 (2000)1737-1742

[88] Yavitt, J.B., Yashiro, E., Cadillo-Quiroz, H., and Zinder, S.H. Biogeochemistry109 (2012)117-131

[89] Yusuf RO, Noor ZZ, Abba AH, Hassan MAA, Din MFM. Renewable and Sustainable Energy Reviews 16:7 (2012)5059-5070. 